\title{
"IT KEEPS GOING AND GOING AND GOING": THE EXPANSION OF FALSE ADVERTISING LITIGATION UNDER THE LANHAM ACT
}

\author{
BRUCE P. KELLER*
}

I

\section{INTRODUCTION}

When section 43(a) of the Lanham Act was enacted fifty years ago, neither Congress nor then-President Truman could have predicted the dramatic effect it later would have on our national commerce. That is particularly true of those Lanham Act provisions that govern advertising and that today have resulted in a form of private regulation-and an entire body of case law-that was nonexistent in the 1940s. Today, virtually all advertising claims made in interstate commerce-whether on product packages, in newspaper and magazine advertisements, in television or radio commercials, or disseminated through new media such as the Internet-fall within the reach of Section 43(a) of the Lanham Act. ${ }^{1}$

\section{II}

\section{The Origins of a Federal Statute Against False Advertising}

\section{A. The Lanham Act of 1946}

Under the Lanham Act's predecessor statute, the legal standard for unfair competition had been very exacting, limiting liability to defendants who had "willfully and with intent to deceive, affix[ed], appl[ied], or annex[ed], or use[d] in connection with any article or articles of merchandise, or any container or containers of the same, a false designation of origin ... tending to falsely identify the origin of the merchandise." In addition, it restricted the class of plaintiffs to "any person, firm, or corporation doing business in the locality falsely indicated as that of origin, or in the region in which said locality is

\section{Copyright (C) 1996 by Law and Contemporary Problems}

* Partner, Debevoise \& Plimpton, New York; former director, and present counsel, International Trademark Association; former member, Advisors Group to the RESTATEMENT (THIRD) OF UNFAIR COMPETITION (1995).

David H. Bernstein and Sandra C. McCallion, associates with Debevoise \& Plimpton, New York, both contributed substantially to this article.

1. See infra text accompanying notes 103-09.

2. Trade-Mark Act of Mar. 19, 1920, ch. 104, § 3, 41 Stat. 533 (repealed 1946). 
situated." 3 This narrow statutory language obviously precluded a wide range of unfair competition claims. ${ }^{4}$

The language of section 43(a), along with the rest of the Lanham Act, eased these restrictive requirements. ${ }^{5}$ Nothing in the legislative history, however, recognizes that a new and potent weapon against false advertising claims was being created. ${ }^{6}$ To the contrary, the focus at the time was that section 43(a) provided an express statutory basis for prohibiting false designations of geographic origin, thus bringing U.S. law into conformity with the provisions of various international conventions to which the United States was a party. ${ }^{7}$

Given this focus, initial interpretations of section 43(a) were quite narrow. Early decisions generally limited the scope of section 43(a) to actions nearly identical to "palming-off" claims at common law, ${ }^{8}$ requiring proof that a defendant had misled prospective customers into believing that the defendant's goods had been produced, sponsored, or approved by the plaintiff. ${ }^{9}$ It was not until 1954 -in a case involving a retailer who advertised a picture of plaintiff's dress for sale but who in fact was selling an "inferior" and "notably different" dress-that section 43(a) first was used in connection with false advertising claims. $^{10}$

Gradually, through a series of court interpretations given during the next three decades, section 43(a) evolved into a vehicle by which private litigants could assert false advertising claims. ${ }^{11}$ Even well into the 1980 s, however, some courts tread cautiously, proposing restrictions on the reach of section 43(a) because it nowhere expressly mentions false advertising. For example, one line of cases held that the only false advertising claims a plaintiff could challenge

3. Id.

4. Even the trademark infringement provisions of the prior law were restrictive. See, e.g., Atlas Mfg. Co. v. Street \& Smith, 204 F. 398, 402 (8th Cir. 1913) (ruling that owner of trademark "Nick Carter" registered for weekly publication featuring fictional detective of same name, could not enjoin distribution of unauthorized motion picture using identical mark because "no exercise of the imagination, however fertile, can transform defendants' film ... into anything resembling a periodical publication").

5. For example, $\S 43(\mathrm{a})$ eliminated the 1920 Act's requirement in unfair competition cases that a defendant's misrepresentations be willful or intentional, expanded liability from misrepresentations concerning a defendant's "merchandise" to those concerning both goods and services, and prohibited a multitude of false descriptions and representations, not merely "false designation[s] of origin." 15 U.S.C. § 1125(a) (1994).

6. See S. REP. No. 79-1333, at 3 (1946), reprinted in 1946 U.S.C.C.A.N. 1274, 1276, Lanham Act, ch. 540, 60 Stat. 427 (1946) (current version at 15 U.S.C. $\$ 1051$ (1994)).

7. Beverly W. Pattishall, The Lanham Trademark Act-Its Impact Over Four Decades, 76 TRADEMARK REP. 193, 212-13 (1986).

8. See, e.g., Chamberlain v. Columbia Pictures Corp., 186 F.2d 923, 925 (9th Cir. 1951); Samson Crane Co. v. Union Nat'l Sales, Inc., 87 F. Supp. 218, 221-22 (D. Mass. 1949), aff'd per curiam, 180 F.2d 896 (1st Cir. 1950).

9. RESTATEMENT (THIRD) OF UNFAIR COMPETITION $\$ 4$ (1995) [hereinafter "RESTATEMENT"].

10. L'Aiglon Apparel, Inc. v. Lana Lobell, Inc., 214 F.2d 649, 650 (3d Cir. 1954).

11. See, e.g., McNeilab v. American Home Prods. Corp., 848 F.2d 34 (2d Cir. 1988); Stiffel Co. v. Westood Lighting Group, 658 F. Supp. 1103 (D. N.J. 1987); American Home Prods. Corp. v. Abbot Labs., 522 F. Supp. 1035 (S.D.N.Y. 1981); Skil Corp. v. Rockwell Int'l Corp., 375 F. Supp. 777 (N.D. III. 1974). 
under the Lanham Act were those made by the defendant about its own products or services, not those made about the plaintiff's competitive products or services. ${ }^{12}$ Other courts permitted Lanham Act challenges addressed only to those false claims involving an "inherent quality or characteristic" of the good or service advertised. ${ }^{13}$

In a few instances, the absence of any express language about false advertising led some courts to reject the applicability of section 43(a) to false advertising claims, or to otherwise expand section 43(a) beyond traditional trademark infringement. ${ }^{14}$ For example, in Coca-Cola Co. v. Procter \& Gamble $\mathrm{Co} .{ }^{15}$ the district court dismissed a claim brought by Coca-Cola, the maker of Minute Maid Orange juice, in which Coca-Cola alleged that television commercials for Citrus Hill orange juice falsely claimed that Citrus Hill was made only from the "heart of the orange." 16 The court declined to reach the merits of that claim because, in its view, "[s]ection 43(a) of the Lanham Act . . . applies only to merchandising practices, equivalent to the misuse of trademarks and palming off of one's goods for another's."17 Although by then the great weight of authority clearly was to the contrary, Coca Cola v. Procter \& Gamble illustrates how it was at least theoretically possible to argue the narrow approach, in some jurisdictions, well into the 1980s.

12. This distinction had its genesis in Bernard Food Indus. v. Dietene Co., 415 F.2d 1279, 1283 (7th Cir. 1969) (holding that "[f]alse advertising or representations made by a defendant about a plaintiff's product are not covered by section 43(a)" and therefore that defendant's allegedly misleading information sheet describing plaintiff's products was not actionable), cert. denied, 397 U.S. 912 (1970), and was applied by some courts as late as 1988. See, e.g., Oil Heat Inst. v. Northwest Nat'l Gas, 708 F. Supp. 1118, 1122 (D. Ore. 1988) (holding advertisements that falsely misrepresented plaintiff's product were not actionable).

13. See, e.g., Fur Info. \& Fashion Council, Inc. v. E.F. Timme \& Son, Inc., 501 F.2d 1048 (2d Cir.) (fur trade association asserted that advertisement for imitation fur, which advertised that one advantage of purchasing garments made with imitation fur was that it spared the lives of tigers and leopards, was false because federal Endangered Species Conservation Act already protected tigers and leopards from being killed for the purposes of clothing manufacture; court dismissed false advertising claim because the commercial said nothing false regarding the quality or characteristics of the imitation furs), cert. denied, 419 U.S. 1022 (1974). Courts continued to reject false advertising claims on this basis as late as 1989. See Hertz Corp. v. Avis, Inc., 725 F. Supp. 170, 171-72 (S.D.N.Y. 1989) (advertisement directed at travel agencies concerning speed with which commissions were paid did not pertain to inherent quality of service of car renting).

14. See, e.g., Clamp-All Corp. v. Cast Iron Soil Pipe Inst., 851 F.2d 478, 491 (1st Cir. 1988) (leaving for another day reconsideration of narrow Samson Crane, 87 F. Supp. 218, interpretation, which limits $\S 43$ (a) to cases of likely source confusion), cert. denied, 488 U.S. 1007 (1989).

15. 642 F. Supp. 936 (S.D. Ohio 1986), rev'd, 822 F.2d 28 (6th Cir. 1987).

16. 822 F.2d at 29. Coca-Cola alleged that, in fact, Citrus Hill, like all other processed orange juice, was made of "the entire interior portion of the orange," not just the heart as Citrus Hill advertised. Id.

17. 642 F. Supp. at 939. The Sixth Circuit Court of Appeals subsequently reversed that decision, stating clearly that $\S 43$ (a) covers claims for false advertising as well as claims for passing off one's products as if they were those of another. $822 \mathrm{~F} .2 \mathrm{~d}$ at 31 . 


\section{B. The Trademark Law Revision Act of 1988}

One of the principal goals of the Trademark Law Revision Act of 1988 ("TLRA"), ${ }^{18}$ which became effective in November 1989, was to eliminate these inconsistencies. It did so in two ways. First, section 43(a) was amended to reflect the majority of the cases extending its application to false advertising cases. $^{19}$ Second, by adding even broader language, the TLRA significantly enhanced the value of section $43(\mathrm{a})$ as a weapon in combatting virtually any type of false advertising or promotional claim. ${ }^{20}$

The TLRA expressly codifies the two primary substantive theories of false advertising cases. Section 43(a)(1) now prohibits, inter alia,

any ... false or misleading representation of fact . . likely to cause confusion, or to cause mistake, or to deceive as to the affiliation, connection or association of such person with another person, or as to the origin, sponsorship, or approval of his or her goods, services, or commercial activities by another person. ${ }^{21}$

Although this provision is applied most frequently to cases of infringement of unregistered trademarks, it also makes actionable claims that an advertiser has falsely suggested that a celebrity endorses or otherwise approves of its goods or services. Decisions before the TLRA's enactment had recognized that such false suggestions of sponsorship or approval could give rise to a Lanham Act

18. Pub. L. No. 100-667, 102 Stat. 3935 (1988) (codified as amended at 15 U.S.C. § 1125(a) (1994)).

19. "Section 35 [of the bill] revises Section 43(a) of the Act (15 U.S.C. $\$ 1125$ (a) (1994)) to codify the interpretation it has been given by the courts .... Since its enactment [section 43(a)] has been widely interpreted as creating, in essence, a federal law of unfair competition ... applied to cases involving . . . actionable false advertising claims." S. REP. No. 100-515, at 40 (Sept. 15, 1988), reprinted in 1988 U.S.C.C.A.N. 3935, 5603; see also 133 CONG. REC. S16,546, S16,547 (daily ed. Nov. 19, 1987) (statement of Sen. DeConcini) ("[T]he [TLRA] strengthens section 43(a) of the act by expressly adopting a series of court decisions holding that the remedies available to owners of federally registered marks are available under section 43(a) ... and that false advertising statements about a competitor's product are unlawful."); Two Pesos, Inc. v. Taco Cabana, Inc., 505 U.S. 763, 783 (1992) (Stevens, J., concurring) ("[I]n the [TLRA] of $1988 \ldots$. . Congress codified the judicial interpretation of $\S 43(\mathrm{a})$, giving its imprimatur to a growing body of case law from the Circuits that had expanded the section beyond its original language." (citation omitted)).

Because Congress took the position that $\$ 43($ a) reflected past judicial decisions but did not expressly address the retroactivity of TLRA, there was a disagreement over whether its terms ought to be applied retroactively to advertising distributed prior to the Act's effective date. Compare ALPO Petfoods, Inc. v. Ralston Purina Co., 913 F.2d 958, 963-64 n.6 (D.C. Cir. 1990) (no retroactive application) with U.S. Healthcare, Inc. v. Blue Cross of Great Phila., 898 F.2d 914, 922 n.9 (3d Cir.) (applying revised § 43(a) retroactively), cert. denied, 498 U.S. 816 (1990) and Eldon Indus., Inc. v. Rubbermaid, Inc., 735 F. Supp. 786, 794 (N.D. Ill. 1990). In Gordon and Breach Science Publishers, S.A. v. American Instit. of Physics, 859 F. Supp. 1521, 1530-31 (S.D.N.Y. 1994), the Court concluded that, because the TLRA not only codified existing case law but went further by imposing new liabilities under $\S 43$ (a) for trade libel and product disparagement, the issue of retroactivity was governed by the Supreme Court's decision in Landgraf v. USI Film Prods., 511 U.S. 244 (1994). Landgraf held that if a statute would impose new duties or liabilities on already completed actions, courts should not apply it retroactively absent "clear congressional intent favoring such a result." 511 U.S.at 280 . at 1505 .

20. "The 1989 amendments ... extend the reach of the Act to any false and misleading representations about the 'nature, characteristics, qualities, or geographic origin of [any person's] goods, services or commercial activities." Monoflo Int'l, Inc. v. Sahm, 726 F. Supp. 121, 126 n.10 (E.D. Va. 1989).

21. 15 U.S.C. $\$ 1125(a)(1)(1994)$. 
violation under section 43(a)'s prior prohibition of the "use ... [of] a false designation of origin, or any false description or representation, including words or other symbols tending falsely to describe or represent the same . ..,22

Section 43(a)(1) now expressly incorporates and makes actionable such claims of false sponsorship or affiliation. Section 43(a)(1) thus has been used not only against advertisements that use a celebrity's name ${ }^{23}$ or photograph ${ }^{24}$ without permission to suggest sponsorship or endorsement, but also against advertisements that use so-called actors or models who sound ${ }^{25}$ or look like wellknown celebrities in a way that suggests sponsorship or endorsement. ${ }^{26}$ The statute even has been used to enjoin advertisements that simply evoke a celebrity's image without her permission. ${ }^{27}$

Section 43(a)(2) addresses the principal remaining theory of false advertising litigation - the prohibition of "any false or misleading description of fact, or false or misleading representation of fact, which ... in commercial advertising or promotion, misrepresents the nature, characteristics, qualities or geographic origin of his or her or another person's goods, services, or commercial activities." 28 These are the theories on which most false comparative advertising cases are predicated. For example, in Abbott Lab. v. Mead Johnson \& Co., Abbott sued Mead for false advertising on a section 43(a)(2) theory, alleging that Mead's advertising claims concerning its oral electrolyte maintenance solution ("OES") were deceptive. ${ }^{29}$ Abbott, the industry leader and creator of OES, which is used to prevent dehydration in infants, offered a glucose

22. Id. (1964). In one pre-TLRA case, for example, a toy company lawfully had acquired the rights to cartoon illustrations drawn in the 1930's by plaintiff Theodore Seuss Geisel, more popularly known as Dr. Seuss. The company had manufactured a line of dolls based on the animal-like characters in those illustrations, characters for which Dr. Seuss subsequently became world famous. Although the rights to the illustrations gave the toy manufacturer the right to manufacture the dolls, it went further in marketing its product: The dolls were sold with hang tags as large as their heads that said, in Dr. Seuss's distinctive lettering, that they were "From the Wonderful World of Dr. Seuss," and from "Dr. Seuss'[s] Merry Menagerie." The court found that the hang tags suggested falsely that Dr. Seuss had authorized or approved the dolls and enjoined further use of the tags. Geisel v. Poynter Prods., Inc., 295 F. Supp. 331, 352-53 (S.D.N.Y. 1968); see also Allen v. Men's World Outlet, Inc., 679 F. Supp. 360 (S.D.N.Y. 1988); Allen v. Nat'l Video, Inc., 610 F. Supp. 612 (S.D.N.Y. 1985).

23. Abdul-Jabbar v. General Motors Corp., 75 F.3d 1391 (9th Cir. 1996).

24. Rostropovitch v. Koch Int'l Corp., 34 U.S.P.Q.2d 1609 (S.D.N.Y. 1995).

25. Waits v. Frito-Lay, Inc., 978 F.2d 1093 (9th Cir. 1992) (false endorsement where singer sounds like Tom Waits), cert. denied, 506 U.S. 1080 (1993).

26. Prudhomme v. Procter \& Gamble Co., 800 F. Supp. 390 (E.D. La. 1992) (complaint states Lanham Act violation where advertisement had model who looks like Chef Paul Prudhomme).

27. White v. Samsung Electronics America, Inc., 971 F.2d 1395 (9th Cir. 1992) (ruling that use in advertisement of robot dressed like game show host Vanna White can give rise to § 43(a) violation). These $\S 43$ (a) claims-known as right of publicity claims-may differ from the right of publicity claims available in many states. As with all Lanham Act claims, the federal right of publicity plaintiff must prove confusion, whereas this may not be an element under state statutory or common law. See, e.g., Allen v. National Video, Inc., 610 F. Supp. 612, 625 (S.D.N.Y. 1985); Abdul-Jabbar, 75 F.3d at 1397-98.

28. 15 U.S.C. $\$ 1125(1)(B)(1994)$.

29. 971 F.2d 6, 7 (7th Cir. 1992). The district court held that Abbott had shown a likelihood of success on the merits but refused to grant an injunction because it concluded that Mead had prevailed on the remaining preliminary injunction factors. The Seventh Circuit affirmed the district court's finding as to the likelihood of success but reversed its denial of the injunction. Id. 
carbohydrate-based product known as Pedialyte. Mead introduced a competing product, Ricelyte, comprised of complex rice syrup solids. A rice-based product would have certain advantages over the carbohydrate-based variant, but it also had numerous marketing problems, such as a short shelf life. The conflict arose over whether Mead's product was rice-based, as Mead claimed in its advertising, or a less desirable rice derivative. ${ }^{30}$ The U.S. Court of Appeals for the Seventh Circuit held that Abbot was entitled to injunctive relief because it could demonstrate a likelihood of success on its claims that (1) Mead's claim that its product was rice-based was literally false, ${ }^{31}$ (2) the name "Ricelyte" was misleading because it "expressly conveys the false message that [the product] contains rice,"32 and (3) Mead's comparison claims were misleading because, although they stated a literal truth about a difference between the two products, the difference allegedly had no therapeutic significance. ${ }^{33}$

In addition to confirming that false advertising is actionable under section 43(a), the TLRA also eliminated other restrictive interpretations of the statute that had developed in the courts. For example, the old "inherent characteristic" requirement has been jettisoned. ${ }^{34}$ Revised section $43(\mathrm{a})(2)$ not only restates the prohibition of any misrepresentation made "in connection with" goods and services, but goes on broadly to proscribe any statement that, in "commercial advertising or promotion, misrepresents the nature [of any] commercial activities." 35 Also abandoned is the Bernard Food distinction between advertising claims about the advertiser's own products or services and those of

30. Id. at $10-11$.

31. Id. at 14.

32. Id.

33. Id. at 15. To obtain relief on this last claim, Abbott would have to show at trial that the statement "while literally true or ambiguous, convey[s] a false impression or [is] misleading in context, as demonstrated by actual consumer confusion." Id. at 13 (citations omitted).

34. See supra note 13 and accompanying text.

35. 15 U.S.C. $\$ 1125$ (a)(1)(B) (1994). That sweeping language would, for example, now appear to proscribe a false statement in a television commercial to the effect that a certain promotion is "an exclusive T.V. offer" made "for the first time on T.V.," when, in fact, the same promotion ran on television last year. Therefore, even if nothing false is stated in the commercial concerning the actual product or service offered, the ad would be actionable. Under at least one interpretation of prior $\S$ 43(a), a contrary result had been reached. See Abernathy \& Closther, Ltd. v. E\&M Advertising, Inc., 553 F. Supp. 834, 837-38 (E.D.N.Y. 1982) (holding that representations that sale was "an exclusive T.V. offer" and made "for the first time on T.V." was false but not actionable because claim related to defendant's mode of advertising rather than to its product). The court in Project Strategies Corp. v. National Communications Corp., 38 U.S.P.Q.2d 1053 (E.D.N.Y. 1995), recently addressed a similar claim brought under the TLRA. Defendants' product packaging for a pet grooming aid included the slogan "As Seen on TV," although defendants had never advertised on television. The court held that defendants' packaging created a likelihood of confusion that consumers would mistake defendants' product for plaintiff's. This holding was heavily influenced by the fact that plaintiff, the original creator of the competing "Pet Mitt" grooming aid, had advertised its product extensively on television and truthfully used a similar statement on its packaging. Interestingly, the court distinguished Abernathy $\&$ Closther not on the basis of the expanded $\$ 43(\mathrm{a})$, but because, unlike the claim in the earlier case, plaintiff's television advertising had made its claim to television fame an inherent quality of its product, which "would have an effect on a consumer's purchasing decision." Id. 
its competitors. Section 43(a) now expressly applies to all false claims about anyone's goods and services. ${ }^{36}$

\section{III}

\section{Key PRinciples of False AdVertising LaW}

Although it significantly expanded the reach of section 43(a), the TLRA also was intended to codify much of the false advertising case law that had evolved in prior years. Thus, many of the basic principles governing such cases remain the same.

\section{A. Standing}

The standards for establishing the right to sue under section 43(a) are quite liberal-virtually anyone who can show a competitive injury has standing to challenge a false advertisement. ${ }^{37}$ Thus, standing has been extended to competitors, ${ }^{38}$ trade associations, ${ }^{39}$ and individuals claiming that advertisements falsely suggest they endorse the goods or services at issue. ${ }^{40}$ Despite the broad language that literally authorizes suits by "any person who believes that he or she ... is likely to be damaged" by the acts it prohibits, standing under section 43(a) has not been extended to commercial plaintiffs with purely prospective interests ${ }^{41}$ or to consumers who have been deceived by false or misleading advertising. ${ }^{42}$

36. 15 U.S.C. § 1125(1)(B) (1994) (holding defendant liable for misrepresentations concerning "his or her or another person's goods, services, or commercial activities").

37. See RESTATEMENT, supra note $9, \S 3 \mathrm{cmt}$. f. (discussing standing under common law false advertising principles).

38. See Coca-Cola Co. v. Tropicana Prods., Inc., 690 F.2d 312 (2d Cir. 1982); Johnson \& Johnson v. Carter-Wallace, Inc., 631 F.2d 186 (2d Cir. 1980). Cf. Stanfield v. Osborne Indus., Inc., 52 F.3d 867, 873 (10th Cir. 1995) (ruling that plaintiff not in competition with defendant lacks standing to bring false advertising claim under Lanham Act).

39. See Camel Hair \& Cashmere Institute of Am., Inc. v. Associated Dry Goods Corp., 799 F.2d 6 (1st Cir. 1986); National Ass'n of Pharmaceutical Mfrs., Inc. v. Ayerst Laboratories, 850 F.2d 904 (2d Cir. 1988).

40. See Waits v. Frito-Lay, Inc., 978 F.2d 1093, 1102 (9th Cir. 1992) (holding that individuals may successfully allege false endorsement only if their protectable interest is "widely" or "well" known), cert. denied, 506 U.S. 1080 (1993). But see Cromer v. Lounsbury Chiropractic Offices, Inc., 866 F. Supp. 960 (S.D. W. Va. 1994).

41. Ortho Pharmaceutical Corp. v. Cosprophar, Inc., 32 F.3d 690 (2d Cir. 1994); Shonac Corp. v. AMKO Int'l, Inc., 763 F. Supp. 919, 934 (S.D. Ohio 1991) (for there to be standing under § 43(a), "competition" must "be present in some discernible way" (citations omitted)).

42. Barrus v. Sylvania, 55 F.3d 468 (9th Cir. 1995); Serbin v. Ziebert Int'l Corp., 11 F.3d 1163 (3d Cir. 1993); Colligan v. Activities Club of New York, Inc., 442 F.2d 686 (2d Cir.), cert. denied, 404 U.S. 1004 (1971). As reported by the House Committee on the Judiciary, the TLRA "would have explicitly acknowledged that consumers have standing to sue for violations of [\$] 43(a)." 134 CONG. REC. H 10419 (daily ed. Oct. 19, 1988) (statement of Rep. Kastenmeier). That language was deleted as part of a compromise between the House and Senate. Rep. Kastenmeier, however, went on to state that he "continue[d] to believe that consumers already have standing to sue under current law." Id. Compare 134 CONG. REC. H 10411 (daily ed. Oct. 19, 1988) (statement of Rep. Fish) (stating that issue of consumer standing requires more analysis). 
For a brief period in the 1980 s, some plaintiffs attempted an end-run around the consumer standing problem by using the Racketeer Influenced and Corrupt Organizations Act ("RICO") ${ }^{43}$ as the basis for consumer class action suits against companies accused of false advertising. The theory behind these class action RICO claims was that a defendant's use of the mails and telephones to convey the false advertisements violated the federal mail and wire fraud statutes and thereby constituted the requisite pattern of racketeering activity. In some cases, the plaintiffs explicitly relied on prior litigation in which the defendants' advertising campaigns had been found to have violated the Lanham Act's prohibitions. ${ }^{44}$

RICO consumer class actions received an initial boost when one early complaint survived a motion to dismiss. In Bauder v. Ralston Purina Co. ${ }^{45}$ the plaintiff filed a class action RICO suit on behalf of all persons who purchased Purina PUPPY CHOW from the defendant between October 1, 1985 and July 30, 1989. The action was based on previous litigation in which Ralston was found to have engaged in false advertising in violation of the Lanham Act. ${ }^{46}$ In response to Ralston's motion to dismiss, the district court concluded, "[i]f the [false] advertisements were paid for in part with funds derived from the wire and mail fraud, the enterprise would fall within [RICO]."47 According to published reports, Ralston thereafter settled the litigation rather than become embroiled in a potentially expensive and time-consuming RICO action. ${ }^{48}$

Most other plaintiffs, however, encountered serious obstacles in their attempts to use RICO in this way. For example, in Savastano v. Thompson Medical Co., a RICO claim arising out of advertising claims for appetite

43. 18 U.S.C. $\$ \S 1961-68$ (1994). RICO makes it "unlawful for any person who has received any income ... from a pattern of racketeering activity ... to use or invest, directly or indirectly, any part of such income ... in acquisition of any interest in, or the establishment or operation of, any enterprise which is engaged in, or the activities of which affect, interstate or foreign commerce." Id. $\S 1962$ (a). To plead a RICO cause of action, a plaintiff must allege the following: (1) that the defendant has received money from a pattern (two or more predicate acts within ten years, id. $\S 1961(5)$ ) of racketeering activity including any offense involving mail fraud or wire fraud, $i d$. $\S 1961(1)(B) ;(2)$ that the defendant invested that money in an enterprise including any individual, partnership, corporation, association, or other legal entity, id. $\$ 1961(4)$; (3) that the plaintiff sustained injury to its business or property as a direct result of defendant's use or investment of income derived from the pattern of racketeering activity, id. $\$ 1964$ (c); and (4) that the enterprise affected interstate commerce, $i d$. $\S$ 1964(a). See, e.g., Shearin v. E.F. Hutton Group, Inc., 885 F.2d 1162, 1165 (3d Cir. 1989). From the plaintiff's point of view, the ability to assert a RICO claim in connection with a false advertising suit has two distinct advantages: (1) the potential recovery of attorneys' fees and treble damages and (2) the availability of a federal forum.

44. E.g., Bauder v. Ralston Purina, No. 89-6513, 1989 WL 143283 (E.D. Pa. Nov. 22, 1989); Savastano v. Thompson Medical Co., 640 F. Supp. 1081 (S.D.N.Y. 1986).

45. Bauder, 1989 WL 143283.

46. ALPO Petfoods, Inc. v. Ralston Purina Co., 720 F. Supp. 194 (D.D.C. 1989), aff'd in part and rev'd in part, 913 F.2d 958 (D.C. Cir. 1990), on remand, 778 F. Supp. 555 (D.D.C. 1991), aff'd in part and rev'd in part, 997 F.2d 949 (D.C. Cir. 1993).

47. Bauder, 1989 WL 143283, at *3.

48. The out-of-court agreement reportedly included $\$ 480,000$ to the plaintiff's attorneys, $\$ 200,000$ to the veterinary schools at the University of Pennsylvania and Cornell University, and cents off coupons for the class of aggrieved consumers. Steven W. Colford, RICO False-Ad Suits Rock Industry, ADVERTISING AGE, Oct. 8, 1990, at 1. 
suppressants, the district court dismissed the complaint because it failed to allege a "pattern of racketeering activity."49 The court also took the opportunity to express its strong disapproval of such consumer RICO suits:

Congress did not intend [RICO] to afford a remedy to every consumer who could trace the purchase of a product to a violation of $\S 1962$. Not only is the legislative history devoid of any such interpretation, but if it were present, it would open up the federal courts to frequent RICO treble damage claims by federalizing much consumer protection law. ${ }^{\text {so }}$

Similarly, in Brittingham v. Mobil Corp. ${ }^{51}$ the U.S. Court of Appeals for the Third Circuit affirmed dismissal of a false advertising RICO class action suit arising out of allegations that Mobil falsely advertised the biodegradability of its Hefty degradable plastic trash bags. ${ }^{52}$ The court's holding rested on the plaintiffs' failure to produce "evidence indicating that the defendant corporations, in contrast to individuals or entities acting on their behalf, took a distinct role in the alleged racketeering activity," 53 otherwise known as the "distinctiveness" requirement. ${ }^{54}$ The court recognized the extreme difficulty plaintiffs face in proving distinctiveness when the named RICO defendant is a corporation, ${ }^{55}$ but noted that the requirement was "in keeping with that [c]ongressional scheme to orient section 1962(c) toward punishing the infiltrating criminals rather than the legitimate corporation which might be an innocent victim of the racketeering activity in some circumstances. ${ }^{.56}$

\section{B. Contributory Liability}

It is self-evident that the party who directly makes the allegedly false or misleading statement is potentially liable. Liability also can be extended to all parties who knowingly play a significant role in accomplishing a wrongful purpose. ${ }^{57}$ Plaintiffs frequently have named research firms, ${ }^{58}$ advertising agen-

49. 640 F. Supp. 1081 (S.D.N.Y. 1986). The court concluded that defendant's alleged criminal activity - the intentional misrepresentation through packaging and advertisements of the performance of a single product-DEXATRIM, could at best be characterized as a "single fraudulent effort, implemented by several fraudulent acts," and thus was insufficient to meet the RICO pattern requirements. Id. at 1085 (citations omitted).

50. Id. at 1087 (citations omitted).

51. 943 F.2d 297 (3d Cir. 1991).

52. See also Strain v. Nutri/System, Inc., No. 90-2772, 1990 WL 209325 (E.D. Pa. Dec. 12, 1990); Rosenstein v. CPC Int'l, Inc., No. 90-4970, 1991 WL 1783 (E.D. Pa. Jan. 8, 1991). In both Nutri/System and $C P C$, the district court, although declining to dismiss a false advertising RICO suit, refused to allow the case to proceed as a class action. Both decisions rejected the argument that all members of the plaintiff class purchased the product for the same reason, i.e., exposure to the allegedly fraudulent advertising. Rather, the courts ruled that each class member would have to present individualized proof of which advertisements he or she saw and whether he or she in fact purchased the product in reliance upon the advertisements. The necessity of such individualized testimony, the courts concluded, presented an insurmountable obstacle to class certification.

53. Brittingham, 943 F.2d at 303.

54. Id. at 300 .

55. Id. at 302 .

56. Id. at 300 (citations omitted).

57. See, e.g., Inwood Labs., Inc. v. Ives Labs., Inc., 456 U.S. 844, 853-54 (1982); Stix Prods., Inc. v. United Merchants \& Mfrs., Inc., 295 F. Supp. 479, 500 (S.D.N.Y. 1968).

58. See, e.g., Grant Airmass Corp. v. Gaymar Indus., 645 F. Supp. 1507 (S.D.N.Y. 1986). 
cies, ${ }^{59}$ and officers of the defendants ${ }^{60}$ as co-defendants for having helped the primary defendants create and distribute the allegedly false advertising. Yet some element of knowledge or involvement must be proven to render a thirdparty liable. ${ }^{61}$

Some of the most interesting analyses of third-party liability come, not in the false advertising context, but in infringement cases. For example, in Fonovisa, Inc. v. Cherry Auction, Inc. ${ }^{62}$ the U.S. Court of Appeals for the Ninth Circuit imposed contributory liability under the Lanham Act against the owner of property at which a swap meet was held. ${ }^{63}$ Cherry Auction repeatedly had been made aware of the unauthorized sales of music recordings in packaging bearing plaintiff's trademarks. In fact, the Sheriff's department had raided the swap meet and seized more than 38,000 counterfeit recordings. A year later the Sheriff had written to Cherry Auction about the ongoing infringement, and the plaintiff directly informed Cherry Auction of the problems surrounding the infringing recordings. ${ }^{64}$

On these facts, the Ninth Circuit reversed the district court's dismissal of the plaintiff's claim alleging contributory trademark infringement. Noting that in another case the Supreme Court had imposed contributory liability under the Lanham Act based on a showing that the defendant either (1) intentionally induced the Lanham Act violation or (2) continued to supply materials knowing that the recipient would use them to engage in such violations, ${ }^{65}$ the Ninth Circuit concluded that Cherry Auction should be liable because it "suppl[ied] the necessary marketplace." ${ }^{\prime 66}$ Under this approach, it is easy to understand why all knowing participants in the creation or distribution of allegedly false advertising copy could be held liable.

\section{Elements of a Cause of Action}

Although the elements of a section 43(a) false advertising claim have been articulated in various ways, there is general acceptance that to succeed on the merits a plaintiff must establish the following five elements: (1) a false statement of fact that has deceived, or has the capacity to deceive, a not

59. See, e.g., Waits v. Frito-Lay, Inc., 978 F.2d 1093 (9th Cir. 1992), cert. denied, 506 U.S. 1080 (1993); Gillette Co. v. Wilkinson Sword, Inc., 795 F. Supp. 662, (S.D.N.Y. 1992); Atlanta Gas Light Co. v. Semaphore Adver., Inc., 747 F. Supp. 715, 723 (S.D. Ga. 1990); Tambrands, Inc. v. Warner-Lambert Co., 673 F. Supp. 1190 (S.D.N.Y. 1987).

60. See, e.g., Donsco, Inc. v. Casper Corp., 587 F.2d 602, 605-06 (3d Cir. 1978).

61. See, e.g., Mini Maid Servs. Co. v. Maid Brigade Sys., Inc., 967 F.2d 1516 (11th Cir. 1992) (holding that franchiser not automatically liable for infringing acts of its franchisee absent intentional inducement to infringe or other knowing involvement with the infringement); Hard Rock Cafe Licensing Corp. v. Concession Servs. Inc., 955 F.2d 1143 (7th Cir. 1992) (holding that flea market operator could be liable for vendor's sales of infringing T-shirts if it knows or has reason to know of infringement).

62. 76 F.3d 259 (9th Cir. 1996).

63. Id. at 265.

64. Id.

65. Id. at 264 (citing Inwood Labs., Inc. v. Ives Labs., Inc., 456 U.S. 844, 854-55 (1982)).

66. Id. at 265 . 
insubstantial segment of the target audience, (2) affecting interstate commerce, (3) in connection with commercial advertising and promotion, (4) that is material, and (5) that is likely to cause injury. ${ }^{67}$ Each of these five elements is discussed below.

1. A False Statement of Fact. It is well-established that if an advertisement is literally false, it violates section 43 (a) and may be enjoined without reference to consumer reaction. ${ }^{68}$ This extends to oral as well as visual claims. ${ }^{69}$

Not all advertisements challenged under section 43(a) as literally false expressly state the alleged falsehood, but rather "by necessary implication ... the statements in the ad are facially false." ${ }^{\prime 0}$ For example, in Tambrands, Inc. v. Warner-Lambert Co. ${ }^{71}$ the defendants advertised that by using their home pregnancy test kit, women could know "in as fast as" or "as soon as" ten minutes-for sure-whether they were pregnant. ${ }^{72}$ In fact, all non-pregnant users had to wait a full thirty minutes to confirm that the test's color change (signaling pregnancy) would not occur. ${ }^{73}$ Moreover, defendants' own study showed that only half of pregnant users of the test obtained positive results in ten minutes or less when using the test on the first day after the expected onset of menses. ${ }^{74}$ As a consequence, the court concluded that the necessary, but false, implication of defendants' "as soon as" ten minutes claim was that they were selling a ten-minute test. ${ }^{75}$

Section 43(a) also prohibits claims that, even if not literally false, still have a tendency to deceive or mislead. ${ }^{76}$ When an advertisement is implicitly false, however, courts will judge its tendency or capacity to deceive not on its own determination of falsity, but by reference to evidence indicating that the public will be misled. Often this takes the form of consumer survey evidence. ${ }^{77}$ The

67. See, e.g., College Savings Bank v. Florida Prepaid Postsecondary Educ. Expense Bd., 919 F. Supp. 756, 764 (D.N.J. 1996). This summary of the elements of a cause of action has not changed significantly in over 20 years. See Cook, Perkiss and Liehe, Inc. v. Northern Cal. Collection Serv. Inc., 911 F.2d 242, 244 (9th Cir. 1990) (quoting Skil Corp. v. Rockwell Int'l Corp., 375 F. Supp. 777, 783-84 (N.D. Ill. 1974)).

68. See, e.g., Castrol, Inc. v. Pennzoil Co., 987 F.2d 939 (3d Cir. 1993); McNeil-P.C.C., Inc. v. Bristol-Myers Squibb Co., 938 F.2d 1544, 1549 (2d Cir. 1991); see also RESTATEMENT \& 2 cmt. d.

69. See, e.g., Coca-Cola Co. v. Tropicana Prods., Inc., 690 F.2d 312, 317 (2d Cir. 1982); Polar Corp. v. Coca-Cola Co., 871 F. Supp. 1520 (D. Mass. 1994).

70. Tambrands, Inc. v. Warner-Lambert Co., 673 F. Supp. 1190, 1193 (S.D.N.Y. 1987).

71. Id.

72. Id.

73. Id.

74. Id. at 1194 .

75. Id.

76. See, e.g., American Home Prods. Corp. v. Johnson \& Johnson, 577 F.2d 160, 165 (2d Cir. 1978) ("Were it otherwise, clever use of innuendo, indirect intimations, and ambiguous suggestions could shield the advertisement from scrutiny precisely when protection against such sophisticated deception is most needed."); see also RESTATEMENT, supra note 9, \& $2 \mathrm{cmt}$. d.

77. See, e.g., Johnson \& Johnson-Merck Consumer Pharmaceuticals Co. v. Rhone-Poulenc Rorer Pharmaceuticals, 19 F.3d 125, 129-30, 132-36 (3d Cir. 1994); Johnson \& Johnson * Merck Consumer Pharmaceuticals Co. v. Smithkline Beecham Corp., 960 F.2d 294, 298 (2d Cir. 1992); see also RESTATEMENT, supra note $9, \S 2 \mathrm{cmt}$. d. 
percentage of consumers who are likely to be deceived by the implied claim for it to be deemed actionable varies from circuit to circuit. One court phrased the requirement as consisting of a "qualitative showing" that a "not insubstantial number of consumers receive[d] a false or misleading impression."

Over the last few years, courts and commentators have focused almost exclusively on consumer survey results as the only probative evidence that an implicit claim has misled the public. ${ }^{79}$ Although it is clear that consumer survey evidence at times may be the most persuasive evidence of an advertisement's tendency or capacity to deceive, ${ }^{80}$ it should not be the exclusive means of assessing implicitly false representations.

For years, sole reliance on survey evidence was justified by citation to an opinion by Judge Lasker of the Southern District of New York. In American Brands, Inc., v. R.J. Reynolds Tobacco Co., ${ }^{81}$ Judge Lasker was asked to determine whether a statement acknowledged to be literally true and grammatically correct nevertheless had a tendency to mislead, confuse, or deceive. ${ }^{82}$ Setting out the manner in which such a determination properly might be made, Judge Lasker stated,

A court may, of course, construe and parse the language of the advertisement. It may have personal reactions as to the defensibility or indefensibility of the deliberately manipulated words ... but the court's reaction is at best not determinative and at worst irrelevant. The question in such cases is-what does the person to whom the advertisement is addressed find to be the message? ${ }^{83}$

78. McNeilab, Inc. v. American Home Prods. Corp., 501 F. Supp. 517, 528 (S.D.N.Y. 1980). To be admissible and considered probative, the survey must be designed and executed by experts to comply with the following fundamental principles: (1) proper universe examined and representative sample drawn from that universe; (2) mode of questioning the interviewees was correct; (3) persons conducting the survey were recognized experts; (4) data gathered were accurately reported; and (5) survey design, questionnaire, and interviewing were in accordance with generally accepted standards of objective procedure and statistics in the field of such surveys. See generally, Bruce P. Keller, A Survey of Survey Evidence, LITIGATION, Fall 1992, at 23; Jacob Jacoby et al., Survey Evidence in Deceptive Advertising Cases Under the Lanham Act: An Historical Review of Comments From the Bench, 84 TRADEMARK REP. 541 (1994).

79. See Herbko Int'l, Inc. v. Gemmy Indus. Corp., 916 F. Supp. 322, 331 (S.D.N.Y. 1996) ("[T]o show confusion and deception, a plaintiff must ordinarily present a consumer reaction survey." (citations omitted)); Compaq Computer Corp. v. Procom Tech., Inc., 908 .F. Supp. 1409, 1427-28 (S.D. Tex. 1995) (ruling that misleading nature of challenged statement not established where no evidence of how "relevant market segment" interpreted advertisement). In Johnson \& Johnson * Merck v. Smithkline Beecham Corp., 960 F.2d 294, 298 (2d Cir. 1992), plaintiff appealed the district court's refusal to consider factors other than consumer survey evidence on the issue of whether the challenged advertisement had a tendency to deceive consumers. Specifically, plaintiff argued that the court erred in failing to consider the "commercial context, defendant's intent to harness public misperception, defendant's prior advertising history, and sophistication of the advertising audience." Id. Nevertheless, the Second Circuit affirmed, stating that "generally, before a court can determine the truth or falsity of an advertisement's message, it must first determine what message was actually conveyed to the viewing audience. Consumer surveys supply such information." Id. (citations omitted). 1980).

80. See, e.g., R.J. Reynolds Tobacco Co. v. Loew's Theatres, Inc., 511 F. Supp. 867, 876 (S.D.N.Y.

81. 413 F. Supp. 1352 (S.D.N.Y. 1976).

82. Id. at 1357 (defendant claimed that its cigarette had the "lowest" tar content, although plaintiff's cigarette had equally low tar content).

83. Id. 
Neither American Brands nor R.J. Reynolds had, according to Judge Lasker, submitted any "evidence of substance" establishing whether the various advertising claims made by the parties were likely to mislead consumers. Accordingly, he denied the injunctive relief each party had requested. ${ }^{84}$

Judge Lasker undoubtedly was correct in stating that the court's personal reaction cannot be the sole factual basis for establishing the tendency or capacity of an ambiguous advertisement to mislead its general audience. It is submitted, however, that Judge Lasker never intended by the above-quoted language to suggest that only consumer surveys can support a finding of likelihood of confusion. Indeed, in McNeilab, Inc. v. American Home Products Corp. ${ }^{85}$ another section 43(a) false advertising case, Judge Lasker stated,

[W] here, as here, the issue is whether true statements are misleading or deceptive despite their truthfulness, it is not enough to place the statements alone before the court. The plaintiff must adduce evidence (usually in the form of market research or consumer surveys) showing how the statements are perceived by those who are exposed to them. This does not mean that the conclusions of market researchers and other expert witnesses are binding on the court. ... Though the court's own reaction to the advertisements is not determinative, as finder of fact it is obliged to judge for itself whether the evidence of record establishes that others are likely to be misled or confused. In doing so, the court must, of course, rely on its own experience and understanding of human nature in drawing reasonable inferences about the reactions of consumers to the challenged advertising. ${ }^{86}$

McNeilab, unlike either party in American Brands, introduced both market survey evidence establishing the tendency of American Home Products' advertising for maximum-strength Anacin to deceive, and evidence that American Home Products intended its commercials to have a deceptive effect. ${ }^{87}$ The court found both forms of proof to be persuasive and enjoined the challenged commercials. ${ }^{8}$

Judge Lasker's explicit recognition that a consumer survey is not the only means by which the tendency or capacity of implicitly false advertisements to mislead the public may be determined is consistent with decisions in a closely related context-section 43(a) trademark infringement cases-determining the likelihood of consumer confusion. Whether the action is for infringement of trademarks or trade dress, or for false advertising not based on explicitly false statements, the central legal question to be resolved in all claims of unfair competition based on section 43(a) is the same: What is the likelihood that consumers will be confused $?^{89}$

84. Id. at 1360. Judge Lasker, however, did enjoin one of Reynolds's claims which, by the date of his decision, had become literally false because of product changes made by American Brands. Id.

85. 501 F. Supp. 517 (S.D.N.Y. 1980).

86. Id. at 525 (emphasis added).

87. Id. at 529 .

88. Id. at 540 .

89. See Two Pesos, Inc. v. Taco Cabana, Inc., 505 U.S. 763, 769 (1992) (trade dress infringement requires showing of likelihood of confusion); Libman Co. v. Vining Indus., Inc., 69 F.3d 1360, 1361 (7th Cir. 1995) (trademark infringement requires proof that consumers likely to be confused about source of allegedly infringing product); L\&F Prods. v. Procter \& Gamble Co., 45 F.3d 709, 711 (2d Cir. 1995) 
The only meaningful distinction between the allegedly false representations involved in infringement and advertising cases is the different subject matter of the representations. In advertising cases, the alleged falsehood usually misrepresents a quality or performance characteristic of goods or services. ${ }^{90}$ In infringement cases, the alleged falsehood usually has to do with the source, origin, or other identifying characteristic of the product or service. ${ }^{91}$ Nevertheless, in many of these infringement cases, the infringing mark or dress only suggests, rather than literally states, that the defendant's goods or services originated, or otherwise are affiliated, with the plaintiff. Therefore, these representations often are of the same suggestive nature as implicitly false advertising claims, making it conceptually difficult to defend the result that market survey research should be the exclusive means of demonstrating the confusing nature of the latter, when it is not required for the former.

In addition, many of the evidentiary criteria used in infringement cases are readily transferable to cases involving implicitly false advertising claims. These criteria include the defendant's intent or purpose in employing the challenged representations, ${ }^{92}$ the recipient audience's sophistication or the degree of attention it is likely to pay to the representation, the similarity of the competing products or services implicated by the representation, the similarity of the marketing channels used, and, of course, evidence of actual confusion. ${ }^{93}$

(proof of false advertising requires showing that disputed ad is literally false or likely to confuse or mislead consumers); Merriam-Webster, Inc. v. Random House, Inc., 35 F.3d 65, 70 (2d Cir. 1994) (likelihood of confusion required for finding of trade dress infringement), cert. denied, $115 \mathrm{~S}$. Ct. 1252 (1995); Fisons Horticulture, Inc. v. Vigoro Ind., Inc., 30 F.3d 466, 472 (3d Cir. 1994) (trademark infringement and unfair competition suit requires proof of likelihood of confusion); Gruner + Jahr USA Pub. v. Meredith Corp., 991 F.2d 1072, 1077 (2d Cir. 1993) ("key element" under § 43(a) is likelihood of confusion); W.W.W. Pharmaceutical Co. v. Gillette Co., 984 F.2d 567, 570-71 (2d Cir. 1993) ( $\$ 43(\mathrm{a})$ false designation of origin and $\S 32$ trademark infringement claims require showing of likelihood of confusion); Bristol-Myers Squibb Co. v. McNeil-P.P.C., Inc., 973 F.2d 1033, 1043 (2d Cir. 1992) (likelihood of confusion is central question in $\S 43$ (a) trade dress infringement case).

90. See RESTATEMENT, supra note $9, \S 3 \mathrm{cmt}$. d.

91. Id. $\$ 20 \mathrm{cmt}$. b.

92. For example, although proof of defendant's intent to mislead is not required to obtain relief, evidence of willfulness or bad faith has been considered as evidence that consumers interpreted the defendant's claim as intended. McNeilab, Inc. v. American Home Prods. Corp., 501 F. Supp. 517, 530 (S.D.N.Y. 1980). Another consequence of evidence of intent is that it can result in a plaintiff avoiding the burden of a consumer survey at the preliminary injunction phase of a case. Abbott Labs. v. Mead Johnson \& Co., 971 F.2d 6, 15 (7th Cir. 1992).

93. Polaroid Corp. v. Polarad Elecs. Corp., 287 F.2d 492, 495 (2d Cir.), cert denied, 368 U.S. 820 (1961). Other circuits apply these or similar standards. See, e.g., DeCosta v. Viacom Int'l, Inc., 981 F.2d 602, 606 (1st Cir. 1992), cert denied, 509 U.S. 923 (1993); Allied Mktg. Group, Inc. v. CDL Mktg., Inc., 878 F.2d 806, 813 (5th Cir. 1989) (referring to these criteria as "factors or 'digits' of confusion"); Schwinn Bicycle Co. v. Ross Bicycles, Inc., 870 F.2d 1176, 1185 (7th Cir. 1989) (looking at digits of confusion); Beer Nuts, Inc. v. Clover Club Foods Co., 805 F.2d 920, 925 (10th Cir. 1986); Freedom Savings and Loan Ass'n v. Way, 757 F.2d 1176, 1182 (11th Cir. 1985); Pizzeria Uno Corp. v. Temple, 747 F.2d 1522, 1577 (4th Cir. 1984) (adding similarity of advertising as a factor); Frisch's Restaurants, Inc. v. Elby's Big Boy of Steubenville, Inc., 670 F.2d 642, 648 (6th Cir. 1982); AMF, Inc. v. Sleekcraft Boats, 599 F.2d 341, 348 (9th Cir. 1979); Scott Paper Co. v. Scott's Liquid Gold, Inc., 589 F.2d 1225, 1229 (3d Cir. 1978). 
A well-conducted consumer research survey certainly is relevant to the determination of the advertisement's capacity to mislead. ${ }^{94}$ Such evidence is viewed most properly, however, as a surrogate for unsolicited examples of actual confusion. Because actual confusion itself has never been a prerequisite to a finding of liability under section 43(a), forced reliance on consumer survey evidence would require section 43(a) plaintiffs to satisfy an unjustifiably higher burden of production in false advertising cases than in challenges to other methods of unfair competition. This distinction does not withstand scrutiny. ${ }^{95}$

2. Interstate Commerce. Subject matter jurisdiction exists where the defendant's advertising substantially affects interstate commerce. ${ }^{96}$ Both intrastate advertising ${ }^{97}$ and activities that take place beyond the territorial limits of the United States can have a sufficiently substantial effect on U.S. commerce to trigger application of the Lanham Act. ${ }^{98}$ Thus, subject matter jurisdiction under the Lanham Act may reach some false advertising in foreign countries. This "extraterritorial jurisdiction" has been applied in at least one reported case, Gordon and Breach Science Publishers v. American Institute of Physics, ${ }^{99}$ in which the false advertising claims were based, inter alia, on

94. RESTATEMENT, supra note $9, \S 2 \mathrm{cmt}$. d.

95. The Second Circuit has held that consumer surveys are not explicitly required in $\S 43$ (a) infringement cases. LeSportsac, Inc. v. K Mart Corp., 754 F.2d 71, 78 (2d Cir. 1985) (trade dress infringement claim brought under $\$ 43$ (a) where plaintiff seeking preliminary injunction). In the false advertising context, some courts have accepted evidence other than a survey to find $\S 43(a)$ injury. See Upjohn Co. v. Riahom Corp., 641 F. Supp. 1209, 1222 (D. Del. 1986) (holding likelihood of false attribution shown where defendant's advertising expressly used materials relating to plaintiff in such a way as to falsely suggest defendant's product associated with plaintiff); Allen v. National Video, Inc., 610 F. Supp. 612, 628-29 (S.D.N.Y. 1985) (declining, for procedural reasons, to rely on consumer survey in $\$ 43(\mathrm{a})$ case involving implicitly false advertising claim). Although survey evidence may not be required, the failure to have one may be costly. For example, in Ortho Pharmaceutical Corp. v. Cosprophar, Inc., 32 F.3d 690 (2d Cir. 1994), the Second Circuit refused to adopt, in lieu of survey evidence, the "advertising linkage" argument successfully asserted in Upjohn. Id. at 697.

96. Before $1988, \S 43$ (a) required that a defendant actually "cause . . goods or services to enter into commerce" before a violation existed. 15 U.S.C. $\$ 1125$ (a) (1946); see, e.g., Skil Corp v. Rockwell Int'l Corp., 375 F. Supp. 777, 783 (N.D. Ill. 1974). The TLRA eliminated this requirement. Now a plaintiff need only show that a defendant, "in connection with any goods or services, or any container for goods, uses in commerce" any false statement. 15 U.S.C. $\$ 1125$ (a) (1994). Thus, all that seems to be required is that the false statement simply affects interstate commerce. See Mother Waddles Perpetual Mission, Inc. v. Frazier, 904 F. Supp. 603, 611 (E.D. Mich. 1995). This liberalization of the interstate commerce requirement is one of a series of changes Congress made to conform the statutory language to the way courts actually had applied the statute in the two decades preceding the amendments. 133 CoNG. REC. S16553 (daily ed. Nov. 19, 1987); see, e.g., U-Haul Int'l, Inc. v. Jartran, Inc., 681 F.2d 1159, 1162 (9th Cir. 1982); Williams Elec., Inc. v. Bally Mfg. Corp., 568 F. Supp. 1274, 1284 (N.D. Ill. 1983); supra note 19.

97. See Larry Harmon Pictures Corp. v. Williams Restaurant Corp., 929 F.2d 662, 665 (Fed. Cir.) (single-location restaurant that serves some interstate travelers affects interstate commerce), cert. denied, 502 U.S. 823 (1991).

98. Cf. Steele v. Bulova Watch Co., 344 U.S. 280 (1952) (holding that resident of Texas who owned a watch factory in Mexico City and stamped the name "Bulova" on watches assembled there was subject to provisions of the Lanham Act for infringement of Bulova watch company's trademark, as the quality of defendant's infringing watches had the potential to reflect adversely on Bulova Watch Company's trade reputation both in the United States and abroad).

99. 905 F. Supp. 169 (S.D.N.Y. 1995). 
defendants' dissemination abroad of a promotional letter and a survey comparing scientific journals published by both parties. ${ }^{100}$ In their summary judgment motion, defendants argued that the Lanham Act was inapplicable because the mailings were sent to France, Japan, and England. ${ }^{101}$ The court denied the motion, holding that the Lanham Act has extraterritorial reach "where (1) the acts in question significantly impact United States commerce; (2) the defendant is an American citizen; and (3) application of the Act would not interfere with the laws of a foreign nation ...."102

3. Commercial Advertising or Promotion. Perhaps the single biggest effect the TLRA has had on false advertising law is that it expressly makes a wide range of misrepresentations - far beyond those made via traditional advertising-subject to its provisions. These can include product labeling, ${ }^{103}$ direct mail solicitations, ${ }^{104}$ general sales talk or bad mouthing, ${ }^{105}$ published articles, ${ }^{106}$ a letter to a single customer, ${ }^{107}$ infomercials, ${ }^{108}$ and on-line advertising (for example, web sites). ${ }^{109}$

100. Id. at 173-74.

101. Id. at 181.

102. Id.

103. See, e.g., Kraft General Foods, Inc. v. Del Monte Corp., 28 U.S.P.Q.2d 1457 (S.D.N.Y. 1993).

104. See, e.g., Birthright v. Birthright, Inc., 827 F. Supp. 1114, 1137-38 (D.N.J. 1993).

105. See, e.g., National Artists Management Co. v. Weaving, 769 F. Supp. 1224, 1229-36 (S.D.N.Y. 1991). But see Licata \& Co. v. Goldberg, 812 F. Supp. 403, 408 (S.D.N.Y. 1993) (holding that the Lanham Act's bar against misleading commercial advertising "would be trivialized if it were applied to statements in oral conversation by an individual sales representative to an individual customer concerning matters which an ordinary listener would recognize as personal opinion as opposed to representations of hard definable facts, such as product descriptions").

106. See, e.g., Semco, Inc. v. Amcast, Inc., 52 F.3d 108, 113 (6th Cir. 1995); Gordon and Breach Science Publishers S.A. v. American Inst. of Physics, 859 F. Supp. 1521, 1532-45 (S.D.N.Y. 1994).

107. See, e.g., Mobius Management Sys., Inc. v. Fourth Dimension Software, Inc., 880 F. Supp. 1005, 1019-21 (S.D.N.Y. 1995). But see Garland Co. v. Ecology Roof Sys. Corp., 895 F. Supp. 274, 276-79 (D. Kan. 1995); Goldsmith v. Polygram Diversified Ventures, Inc., 37 U.S.P.Q.2d 1321, 1326 (S.D.N.Y. 1995); American Needle \& Novelty Inc. v. Drew Pearson Mktg., Inc., 27 U.S.P.Q.2d 1059, 1062-63 (N.D. Ill. 1993).

108. See, e.g., College Sav. Bank v. Florida Prepaid Postsecondary Educ. Expense Bd., 919 F. Supp. 756, 764 n.9 (D.N.J. 1996) (noting that "promotion" might be sufficiently broad to include statements not part of any formal promotion or advertising campaign); Media Arts Int'l, Ltd. v. Trillium Health Prods., 25 U.S.P.Q.2d 1764 (E.D. Pa. 1992).

109. Comedy III Prods., Inc. v. Class Publications., Inc., 1996 WL 219636 (S.D.N.Y. May 1, 1996) (former licensee's on-line advertising of Three Stooges products violates \& 43(a) of Lanham Act). 
However broad the reach of section $43(\mathrm{a}),{ }^{110}$ for constitutional reasons the Lanham Act does not reach noncommercial speech. ${ }^{111}$ In recent years, as corporations, trade associations, and others have taken space and time in paid media to express their views on a variety of issues, they have been increasingly subject to challenge for allegedly misrepresenting the facts that support their respective positions. In the course of these challenges, a number of courts have been required to decide whether the objectionable speech is entitled to full First Amendment protection.

In one recent example, Wojnarowicz v. American Family Association, ${ }^{112}$ a national promotional effort was launched to prevent the public funding of "offensive" and "blasphemous" art by the National Endowment for the Arts. The plaintiff, a multimedia artist, sought to enjoin the distribution of a pamphlet published by the defendant that contained photographic reproductions of the plaintiff's allegedly offensive works ${ }^{113}$ and which was designed to rally support for the defendant's cause. The complaint alleged, inter alia, a claim for false designation of origin under section 43(a)(1) of the Lanham Act.

In addressing the plaintiff's Lanham Act claim, the district court noted that, although section 43(a) as revised "encompasses a broad range of misrepresentations," including disparagement of another's product, the Act was never intended to "stifle criticism of the goods or services of another by one . . who is not engaged in marketing or promoting a competitive product or service." 114 Indeed, the court noted that the legislative history of the TLRA specifically distinguished between false or misleading commercial advertisements or promotions and political speech that may contain "consumer or editorial comment." 115 The court held that because the defendant's pamphlet was intended to be political speech and was not "employed in the "advertising or

110. See National Artists Management Co. v. Weaving, 769 F. Supp. 1224 (S.D.N.Y. 1991) (disparaging remarks about former employer to several former clients by telephone were actionable under $\$ 43$ (a) where former employee was beginning competing business); Holmsten Ice Rinks, Inc. v. Burley's Rink Supply Inc., 14 U.S.P.Q.2d 1492 (D. Minn. 1990) (§ 43(a) applies to disparaging statements about competitor's product in catalogue, and noting difference between disparagement and defamation). But see Monoflo Int'l, Inc. v. Sahm, 726 F. Supp. 121 (E.D. Va 1989) (\$ 43(a) applies only to misrepresentations concerning goods or services and not to misrepresentations concerning a party's status or commercial relationships that are not connected to the quality, nature, or characteristics of any product or service).

111. Commercial speech, as contrasted with non-commercial or expressive speech, was defined by the Supreme Court in Virginia State Board of Pharmacy v. Virginia Citizens Consumer Council, Inc., 425 U.S. 748, 762 (1976), as "speech which does no more than propose a commercial transaction." Such speech enjoys a lesser degree of First Amendment protection. Id. at 771-72 n.24.

112. 745 F. Supp. 130 (S.D.N.Y. 1990).

113. Plaintiff's art works included paintings, photographs, collages, sculptures, and films directed at bringing attention to the devastation wrought upon the homosexual community by the AIDS epidemic. Much of plaintiff's art "incorporate[d] sexually explicit images for the avowed purpose of shaping community attitudes towards sexuality." Id. at 133 .

114. Id. at 141.

115. Id. at 142 (citing S. 1883, 101st Cong., 1st Sess., 135 CoNG. REC. 1207, 1217 (Apr. 13, 1989) (ruling that non-commercial speech "such as a Consumer Report which reviews and may disparage the quality ... of products, [and] misrepresentations made by interested groups which may arguably disparage a company and its products" are not encompassed by $\S 43(\mathrm{a})$ ). 
promotion' of goods or services," the plaintiff had failed to state a claim under the Lanham Act. ${ }^{116}$

4. Materiality. A statement that is likely to influence purchasing decisions is material. ${ }^{117}$ In appropriate circumstances, an omission, if material, may also qualify as a "false statement." The Tambrands v. Warner-Lambert case discussed above involved an advertising claim that did not make clear to women that those who were not pregnant always had to wait a full thirty minutes to receive an accurate result. ${ }^{119}$ The court held that the failure to disclose this fact was a material omission that was actionable under the Lanham Act. ${ }^{120}$

Conversely, omissions that are not likely to affect a consumer's purchasing decision are not actionable. In Universal City Studios v. Sony Corp. of America,${ }^{121}$ the plaintiff sought to compel the defendant, a manufacturer of VCRs, to disclose the plaintiff's view (subsequently rejected by the Supreme Court ${ }^{122}$ ) that taping TV shows off the air infringed its copyrights. ${ }^{123}$ In denying their request for relief, the district court held that "it cannot be said that as conceived or enacted [section 43(a)] was designed to make all failures to disclose actionable." 124 Similarly, in McNeilab, Inc. v. American Home Products Corp. ${ }^{125}$ the plaintiff sought to compel the defendant to disclose that Anacin, advertised as containing "the pain reliever doctors recommend most," actually contained aspirin, a drug that has some side effects. ${ }^{126}$ In rejecting the plaintiff's claim, the court expressly held that "a failure to inform consumers of something, even something that they should know, is not per se a misrepresentation actionable under section 43(a)." 127 In both of these cases it is clear that

116. Id. The court, however, held in favor of the artist under the New York Artists' Authorship Rights Act. Plaintiff received injunctive relief and nominal damages in the amount of \$1. Id. at 149 . 117. See, e.g., Skil Corp. v. Rockwell Int'l Corp., 375 F. Supp. 777, 783 (N.D. Ill. 1974); see also RESTATEMENT, supra note $9, \S 3 \mathrm{cmt}$. b.

118. As originally drafted, the TLRA would have made omissions of material information that result in misrepresentations expressly actionable. According to the Senate Judiciary Committee, however, the material omissions provisions did not make it out of committee because of

concerns that [the omissions provision] could be misread to require that all facts material to a consumer's decision to purchase a product or service be contained in each advertisement. Currently, the question of when section 43(a) reaches failure to disclose information material to a consumer's purchasing decision is an open question in the courts. The committee does not through the deletion indicate that it condones deceptive advertising, whether by affirmative misrepresentation or material omission, and leaves to the courts the task of further developing and applying this principle under section 43(a).

S. REP. NO. 100-515, at 41 (1988), reprinted in 1988 U.S.C.C.A.N. 5577, 5603-04.

119. 673 F. Supp. 1190 (S.D.N.Y. 1987).

120. Id. at 1194 .

121. 429 F. Supp. 407 (C.D. Cal. 1977).

122. See Sony Corp. of Am. v. Universal Studios, Inc., 464 U.S. 417 (1984).

123. Universal City Studios, 429 F. Supp. at 408.

124. Id. at 410.

125. 501 F. Supp. 517 (S.D.N.Y. 1980).

126. Id. at 532 .

127. Id. 
the particular facts omitted simply were not sufficiently material to the purchasing decision to warrant compelled disclosure.

5. Likely to Cause Plaintiff Injury. A plaintiff in a false advertising case brought under section 43(a) does not have to prove actual injury, just that the advertisement is likely to cause damage. ${ }^{128}$ The likely harm must be competitive and direct, not a derivative injury. ${ }^{129}$ In practice, courts often treat the injury requirement in a way reminiscent of the standing analysis because the type of injury to be proven, such as sales lost to the defendant or harm to plaintiff's good will or reputation, necessarily entails an assessment of whether the plaintiff enjoys a reasonable interest to be protected against the alleged harm. ${ }^{130}$

In addition, a false advertising plaintiff must show that the injury alleged actually was caused by the challenged statement. Thus, in Grove Fresh Distribution, Inc. $v$. Everfresh Juice Co., ${ }^{131}$ the plaintiff offered "no facts supporting the conclusion that the customers were lost" to the defendant charged with false advertising, so the court could not find that the defendant's challenged statement had caused the injury.

The plaintiff in Nikkal $v$. Salton ${ }^{132}$ also failed to prove causation in its action against a competing manufacturer of ice cream machines. Although Nikkal had suffered a loss in sales after Salton began competing with its allegedly false advertising, Nikkal could not prove the requisite injury. The court found that Nikkal's own marketing strategy played the predominant role in the decline of sales, ${ }^{133}$ quite apart from the challenged packaging. ${ }^{134}$ In short, even assuming Salton's advertising was deceptive, Nikkal could not recover if it was unable to prove "by a preponderance of the evidence, that Salton's alleged wrongdoing caused it to sustain some damage."135

\section{IV}

\section{EMERging CONSTITUTIONAL IsSUES IN FALSE AdVERTISING Litigation}

The expanded reach of section 43(a) has resulted in a commensurate reduction in the types of claims that do not fall within its scope. One area ripe for further litigation, however, is the contention that a defendant's advertising constitutes speech fully protected by the First Amendment. ${ }^{136}$ This defense has been used with varying degrees of success, and at least one court has

128. See Johnson \& Johnson v. Carter-Wallace, Inc., 631 F.2d 186, 190 (2d Cir. 1980).

129. RESTATEMENT, supra note $9, \S 3 \mathrm{cmt}$. f.

130. See supra text accompanying notes $37-56$; RESTATEMENT, supra note $9, \S 3 \mathrm{cmt}$. $\mathrm{f}$.

131. No. 89 C 1113, 1992 WL 38998, at *2 (N.D. Ill. Feb. 24, 1992).

132. 735 F. Supp. 1227 (S.D.N.Y. 1990).

133. Id. at $1237-38$.

134. Id. at 1238 .

135. Id. (emphasis in original).

136. See L.L. Bean, Inc. v. Drake Publishers, Inc., 811 F.2d 26 (1st Cir.), cert. denied, 483 U.S. 1013 (1987). 
rejected a Lanham Act claim on the grounds that the speech in question was "artistic expression" protected by the First Amendment and was not "primarily intended to serve a commercial purpose." 137 Generally speaking, however, use of the First Amendment in defense of misleading commercial advertising claims has proved unavailing. As the Second Circuit stated in Vidal Sassoon, Inc. v. Bristol-Meyers Co., ${ }^{138}$ "[m]isleading commercial speech is beyond the protective reach of the First Amendment. The Lanham Act's content-neutral prohibition of false and misleading advertising does not arouse First Amendment concerns that justify alteration of the normal standard for preliminary injunctive relief." 139

There are, however, two noteworthy instances in which the First Amendment clearly does come into play. The first is found in cases where the allegedly misleading commercial speech is connected closely to activities that traditionally have enjoyed full First Amendment protection, such as publishing and motion picture production. ${ }^{140}$ The second exception is found in cases where, although the speech may have been found deceptive, the scope of injunctive relief is deemed excessively broad and likely to affect future speech that is not necessarily false. Both instances are discussed below.

137. See Rogers v. Grimaldi, 695 F. Supp. 112, 120-21 (S.D.N.Y. 1988) (action under $\S 43(a)$ of Lanham Act by actress Ginger Rogers against makers of movie "Ginger and Fred"), aff'd, 875 F.2d 994 (2d Cir. 1989); see also Cliff's Notes, Inc. v. Bantam Doubleday Dell Publishing Group Inc., 886 F.2d 490 (2d Cir. 1989) (parody not infringing in light of public interest in free expression); Girl Scouts of the United States of Am. v. Bantam Doubleday Dell Publishing Group, Inc., 808 F. Supp. 1112, 1121 (S.D.N.Y. 1992) (in action alleging that titles of children's books infringe plaintiff's marks, issue is whether risk of confusion as to source of books is greater than public interest in artistic expression), affd, 996 F.2d 1477 (2d Cir. 1993); Yankee Publishing, Inc. v. News Am. Publishing, Inc., 809 F. Supp. 267 (S.D.N.Y. 1992) (magazine cover's communication of an expressive message by reference to the Old Farmer's Almanac protected by First Amendment); New Kids on the Block v. News Am. Publishing, Inc., 745 F. Supp. 1540 (C.D. Cal. 1990) (concluding under Rogers that First Amendment protects news gathering and dissemination activities from Lanham Act challenge), aff'd on other grounds, 971 F.2d 302 (9th Cir. 1992) (because use of mark was protected fair use, no need to reach questions of constitutional law).

138. 661 F.2d 272 (2d Cir. 1981).

139. Id. at $276 \mathrm{n} .8$ (citations omitted); see also U.S. Healthcare, Inc. v. Blue Cross of Greater Philadelphia, 898 F.2d 914, 928 n.15 (3d Cir.) ("In the context of government restriction of speech, false and misleading commercial speech have no First Amendment value."), cert. denied, 498 U.S. 816 (1990); American Home Prods. Corp. v. Johnson \& Johnson, 654 F. Supp. 568, 590 (S.D.N.Y. 1987) ("[T]here is a strong public interest in the prevention of misleading advertisements .... Where the advertising in question is misleading, this interest prevails over the advertiser's right of commercial speech." (citations omitted)).

140. Many of these cases arise in the context of traditional trademark infringement claims. At first blush, these may appear conceptually distinct from "core" false advertising cases but in fact they are not. The central question to be resolved in all unfair competition claims based on $\S 43$ (a) of the Lanham Act is the same: What is the likelihood of consumer confusion? In false advertising cases, the alleged falsehood relates to some quality or performance characteristic. In infringement cases, the falsehood relates to the alleged source of or affiliation with the goods or services. In both instances, either an express or implied falsehood is involved. See Bruce P. Keller, Private Regulation of Advertising Under Section 43(a) of the Lanham Act, ANN. SURV. AM. L. 563, 576-77 (1985). 


\section{A. Commercial Speech Promoting "Core" First Amendment Activities}

A series of recent cases illustrates the apparently greater latitude accorded commercial speech that, although arguably misleading, promotes activities traditionally protected under the First Amendment. In Rogers v. Grimaldi, ${ }^{141}$ Ginger Rogers claimed that "Ginger and Fred," used as the title for a fictional motion picture about two Italian cabaret dancers who imitated Rogers and Fred Astaire, created the false impression that Rogers herself either had some involvement in the movie or that the movie was actually about her. ${ }^{142}$ As neither impression was accurate, Rogers sued under, among other theories, section 43(a) of the Lanham Act and the common law right of publicity. ${ }^{143}$

At the district court level, Rogers lost a summary judgment motion when the court concluded that, because of the title's undisputed artistic relevance to the film, neither the Lanham Act nor the common law claims could be sustained. $^{144}$ The Second Circuit affirmed, but in so doing it found the district court's analysis unduly restrictive of the Lanham Act given the less than full level of protection enjoyed by commercial speech. It noted that, although

[m]ovies, plays, books, and songs are all indisputably works of artistic expression[,] . . . they are also sold in the commercial marketplace like other more utilitarian products, making the danger of consumer deception a legitimate concern that warrants some government regulation. ... The purchaser of a book, like the purchaser of a can of peas, has the right not to be misled. ${ }^{145}$

At the same time, however, the Second Circuit expressly recognized that when, in the case of a movie title, the artistic and commercial elements "are inextricably intertwined," the scope of the Lanham Act must be interpreted with an eye toward "First Amendment values."146 The court therefore adopted a balancing test designed to weigh the public interest in avoiding confusion against the public interest in free expression. ${ }^{147}$ It stated that

[i]n the context of allegedly misleading titles using a celebrity's name, that balance will normally not support application of the [Lanham] Act unless the title has no artistic relevance to the underlying work whatsoever, or, if it has some artistic relevance, unless the title explicitly misleads as to the source or the content of the work..$^{148}$

Applying this rule to the movie title "Ginger and Fred," the Second Circuit affirmed the grant of summary judgment. ${ }^{149}$ It held that, despite the possibility that some consumers might be misled, such risk was "outweighed by the

141. 875 F.2d 994 (2d Cir. 1989).

142. Id. at $996-97$. Rogers relied on survey evidence that demonstrated about $14 \%$ of 201 respondents thought the title suggested Rogers was involved in the making of the film. Id. at $1001 \mathrm{n} .8$.

143. Id. at 997 . "The common law right of publicity ... grants celebrities an exclusive right to control the commercial value of their names and to prevent others from exploiting them without permission." Id. at 1003-04.

144. Id. at 997.

145. Id. (citations omitted).

146. Id. at 998 .

147. Id. at 999 .

148. Id. (footnote omitted).

149. Id. at 1001-02. 
danger that suppressing an artistically relevant though ambiguous title will unduly restrict expression." 150 For similar reasons, the court held that the right of publicity must also be circumscribed to accommodate First Amendment concerns. ${ }^{151}$

In Cliffs Notes, Inc. v. Bantam Doubleday Dell Publishing Group, Inc., ${ }^{152}$ the Second Circuit expanded the Rogers approach to cover all "Lanham Act claims against works of artistic expression." 153 The plaintiff in Cliffs Notes argued that there was a great risk of consumer confusion between the famous cover for its study guides to "classic" books and the defendant's parody of the guides, "Spy Notes," which replicated the distinctive yellow color, black diagonal stripes, and black lettering of "Cliffs Notes."154 The Second Circuit disagreed for two reasons. First, it noted that more risk of confusion is to be tolerated in parody cases because

[a] parody must convey two simultaneous-and contradictory-messages: that it is the original, but also that it is not the original and is instead a parody. To the extent that it does only the former but not the latter, it is not only a poor parody but also vulnerable under trademark law, since the customer will be confused. ${ }^{155}$

Moreover, the court concluded that the actual risk of confusion created by "Spy Notes" was slight ${ }^{156}$ and was outweighed by the "well-established public interest in parody." 157 It therefore vacated the prepublication injunction the district court had issued against distribution of "Spy Notes." 158

Another way in which courts have attempted to articulate the balance between First Amendment concerns and allegedly deceptive commercial speech is found in Yankee Publishing, Inc. v. News America Publishing, Inc., where it

150. Id. at 1001 .

151. Id. at 1004 .

152. 886 F.2d 490 (2d Cir. 1989).

153. Id. at 495 .

154. Id. at 492 .

155. Id. at 494 (emphasis in original).

156. Id. at 497. If the parody is obvious, there will be no likelihood of confusion because consumers will understand it to be a parody. E.g., Marriott Corp. v. Ramada, Inc., 826 F. Supp. 726, 728 (S.D.N.Y. 1993); Eveready Battery Co. v. Adolph Coors Co., 765 F. Supp. 440, 450 (N.D. Ill. 1991). See generally Bruce Keller \& David Bernstein, As Satiric As They Wanna Be: Parody Lawsuits Under Copyright, Trademark, Dilution and Right of Publicity Laws, 85 TRADEMARK REP. 239, 253-56 (1995). The same is true of certain types of exaggerated claims, which, although not true parodies, use humor to convey certain messages. See, e.g., American Express Travel Related Servs. Co. v. Mastercard Int'l, Inc., 776 F. Supp. 787, 790 (S.D.N.Y. 1991).

However, if the parody is too subtle and consumers are not automatically aware that it is a parody, the defense will fail. See, e.g., Schieffelin \& Co. v. Jack Co. of Boca, Inc., 850 F. Supp. 232, 247-50 (S.D.N.Y. 1994). One way to determine whether consumers get the joke or take it seriously is to commission a survey. E.g., Wendy's Int'l, Inc. v. Big Bite, Inc., 576 F. Supp. 816, 823-24 (S.D. Ohio 1983).

157. Cliffs Notes, 886 F.2d at 495; see also L.L. Bean, Inc. v. Drake Publishers, Inc., 811 F.2d 26, 33 (1st Cir.) (noting that court's reluctance to apply state antidilution statute to parody featuring unauthorized use of plaintiff's mark "stems from a recognition of the vital importance of parody"), cert. denied, 483 U.S. 1013 (1987).

158. Cliffs Notes, 886 F.2d at 497; see also Girl Scouts of the United States v. Bantam Doubleday Dell Publishing Group, Inc., 808 F. Supp. 1112, 1121 (S.D.N.Y. 1992) (expanding Rogers test beyond parody and commentary to books of children's fiction), aff'd, 996 F.2d 1477 (2d Cir. 1993). 
was held that no significant likelihood of confusion ensued from a cover of $\mathrm{New}$ York magazine designed to look like the Old Farmer's Almanac. ${ }^{159}$ According to the Yankee Publishing court, where deceptive commercial speech, such as the unauthorized use of another's trademark,

is part of a communicative message and not a source identifier, the First Amendment is implicated .... Thus, where the unauthorized use of a trademark is for expressive purposes of comedy, parody, allusion, criticism, news reporting, and commentary, the law requires a balancing of the rights of the trademark owner against the interests of free speech. ${ }^{160}$

In a similar case, the musical group New Kids on the Block brought a Lanham Act claim against Star magazine and USA Today for these publications' use of a telephone poll to ascertain the group's popularity, alleging that the defendants' polls were likely to confuse the public with respect to the relationship between the group and defendants" "900" number telephone services. ${ }^{161}$ Callers to the 900 numbers were asked to vote (at a charge of fifty cents or ninety-five cents per minute, depending on the publication) on whether they liked the group and which member they found most attractive. In the case of Star magazine, callers also were solicited to participate in a separate 900 number service trivia game. Based upon these facts, the court granted defendants' summary judgment motions, holding that

the First Amendment provides immunity . . . unless . . . use of the plaintiffs' trademark was wholly unrelated to news gathering and dissemination, misleading as to content, or falsely and explicitly denoted authorship, sponsorship, or endorsement . . . The Court finds that the defendants were involved in the constitutionally protected activity of news gathering and dissemination when they conducted [the] poll . . . ${ }^{162}$

Two things are clear from the foregoing line of cases. First, although misleading commercial speech may be beyond the protection of the First Amendment, ${ }^{163}$ artistic, communicative or expressive commercial speech is not. When the allegedly misleading speech is closely linked to "core" First Amendment activities like political speech, parody, satire, books, movies, news reporting and the like, courts are willing to find that allegations of misleading speech ought to be filtered through First Amendment concerns. ${ }^{164}$

159. 809 F. Supp. 267 (S.D.N.Y. 1992).

160. Id. at 276; see also Brach Van Houten Holding, Inc. v. Save Brach's Coalition for Chicago, 856 F. Supp. 472, 476 (N.D. Ill. 1994) (coalition attempting to prevent plant closure enjoined from unauthorized use of plaintiff's mark, where such injunction "will not unduly hinder [coalition's] ability to communicate its ideas").

161. New Kids on the Block v. News Am. Publishing, Inc., 745 F. Supp. 1540, 1542 (C.D. Cal. 1990), aff'd, 971 F.2d 302 (9th Cir. 1992).

162. Id at 1541-42. But see No Fear, Inc. v. Imagine Films, Inc., 38 U.S.P.Q.2d 1374, 1376 (stating that "the more reasoned analysis indicates that cases of parody or competing artistic titles should not be singled out for preferential treatment," but that a traditional likelihood of confusion analysis should be weighed against First Amendment concerns, and suggesting that plaintiff's showing of confusion must be "particularly compelling").

163. See supra note 137 and accompanying text.

164. It is not enough, however, simply to allege that First Amendment issues are at stake. In MGMPathe Communications Co. v. Pink Panther Patrol, 774 F. Supp. 869, 876 (S.D.N.Y. 1991), the allegation that a gay activist group called Pink Panther Patrol engaged in political speech did not shield the Patrol 
Second, although arising in the context of disputes between private commercial entities, these cases also are consistent with the Supreme Court's Virginia Board analysis in that they turn on whether the speech involved does "no more than propose a commercial transaction."165 The allegedly misleading speech in Rogers, Cliffs Notes, Yankee Publishing, and New Kids did not fit the Court's classic definition of commercial speech, in part because the expression itself, rather than a separate product or service, was being sold. Because the challenged speech had independent value, apart from the transaction proposed, the courts could not readily classify the speech as purely commercial. ${ }^{166}$

\section{B. First Amendment Limitations on Injunctive Relief}

As suggested above, there is little doubt but that the First Amendment permits courts to enjoin advertisers and others from disseminating "facially false" commercial speech. Courts have recognized, however, that the First Amendment limits their ability to enjoin inherently nondeceptive speech that has the potential to be used in a deceptive manner. As a result, injunctions in false advertising cases must be crafted so that they balance the state's interest in regulating false and deceptive advertising with the First Amendment protections afforded truthful commercial speech. A pair of cases illustrates how courts have used disclaimers to strike this balance.

In Better Business Bureau of Metropolitan Houston, Inc. v. Medical Directors, Inc. ${ }^{167}$ two local chapters of the Better Business Bureau (the "BBB") sued under the Lanham Act and the Texas Deceptive Trade Practices-Consumer Protection Act to prevent the defendant, owner of a chain of weight-loss clinics, from disseminating advertising that implied the BBB had investigated and endorsed the defendant's weight-loss programs. In fact, the BBB had neither

from a finding of trademark infringement. See also Dallas Cowboys Cheerleaders, Inc. v. Pussycat Cinema, Ltd., 604 F.2d 200 (2d Cir. 1979) (rejecting assertion that defendant's unauthorized use of plaintiff's mark in pornographic film constituted parody entitled to First Amendment protection).

165. Virginia State Board of Pharmacy v. Virginia Citizens Consumer Council, Inc., 425 U.S. 748, 762 (1976).

166. See also Lucasfilm, Ltd. v. High Frontier, 622 F. Supp. 931, 934 (D.D.C. 1985) (rejecting Lanham Act claims brought by producer of "Star Wars" films against public interest groups for their use of the term in voiced objections to then-President Reagan's Strategic Defense Initiative because trademark laws "do not reach into the realm of public discourse to regulate the use of terms used outside the context of trade"). Where a commercial transaction clearly has been proposed, however, the promotional nature of the speech will prevent successful reliance on the First Amendment. See White v. Samsung Elecs. Am., Inc., 971 F.2d 1395, 1401 (9th Cir. 1992) (even though defendants had intended to spoof TV-hostess Vanna White and "Wheel of Fortune" in television commercial, "parody defense" found inapplicable because the "primary message" of commercial was to promote Samsung's products), cert. denied, 113 U.S. 2443 (1993). But see Eveready Battery Co., Inc. v. Adolph Coors Co., 765 F. Supp. 440 (N.D. Ill. 1991) (holding defendant's commercial featuring famous actor wearing bunny ears, tail, and feet to be a parody of plaintiff's mechanical bunny commercials and therefore immune to claims under Copyright Act, Lanham Act and state antidilution statute).

167. 681 F.2d 397 (5th Cir. 1982). 
endorsed the defendant's programs nor commissioned any investigation of the defendant's business. ${ }^{168}$

On the BBB's motion for a preliminary injunction, the district court enjoined the defendant not only from representing that the BBB had in any way endorsed or approved of its weight-loss programs, but also from "causing to be used either of the designations 'Better Business Bureau' or 'BBB,' or any other designation similar thereto, in connection with the advertising or promotion of any of [the d] efendants' weight reduction centers or services." ${ }^{169}$ On appeal, the Fifth Circuit took issue with the district court's complete ban on any reference to the $\mathrm{BBB}$ :

The issue raised by the district court's restriction on the content of [the defendant's] advertisements is ... precisely one of commercial speech: whether an initial determination of deception in advertising may, in a manner consonant with the first amendment, warrant an absolute prohibition on all further statements containing reference to the same topic. Well-articulated principles delineating the protections to commercial expression say not. ${ }^{170}$

Ruling that "the appropriate remedy is not less speech, but more," the Fifth Circuit modified the district court's injunction "to require only that references to the [BBB] contained in [the defendant's] advertising contain a prominent disclaimer of the [BBB]'s endorsement of [the defendant] or its program." 171

The First Amendment's preference for effective disclaimers over injunctive relief was further explained in Consumers Union of United States, Inc. v. General Signal Corp. ${ }^{172}$ There, the publisher of Consumer Reports magazine had sued under various provisions of the Copyright Act and section 43(a) of the Lanham Act to enjoin the defendant, manufacturer and marketer of the "Regina Powerteam" vacuum cleaner, from using a favorable Consumer Reports review in broadcast advertising of its product. Although the defendant's advertising contained clear disclaimers stating that "Consumer Reports is not affiliated with Regina and does not endorse products," the plaintiff contended that it was injured despite such disclaimers because "any mention of [Consumers Union] in commercial advertising will diminish its effectiveness as an unbiased evaluator of products." 173

Based upon the plaintiff's showing of infringement under the Copyright Act, the district court granted the plaintiff's motion for a preliminary injunction. On appeal, however, the U.S. Court of Appeals for the Second Circuit vacated the injunction, holding that it was supported by neither the Copyright Act nor the Lanham Act. ${ }^{174}$ With regard to the plaintiff's Lanham Act challenge, the

168. Id. at 399.

169. Id. at 404 .

170. Id. at 405.

171. Id.

172. 724 F.2d 1044 (2d Cir. 1983), cert. denied, 469 U.S. 823 (1984).

173. Id. at 1050 (emphasis in original) (footnote omitted).

174. Id. at 1051, 1053. 
Second Circuit stated in no uncertain terms that adequate disclaimers are to be preferred to injunctive relief as a remedy for "confusing" commercial speech:

The district court in the instant case erred in enjoining Regina from making any reference to the favorable Consumer Reports rating. If the record truly evinced a likelihood of consumer confusion (which it does not), the proper course would have been to require a clear disclaimer. The First Amendment demands use of a disclaimer where there is a reasonable possibility that it will suffice to alleviate consumer confusion. ${ }^{175}$

Taken together, Better Business Bureau and Consumers Union demonstrate that an appropriate disclaimer can be used both by an advertiser to prevent the imposition of injunctive relief and by the courts to shape an injunction so that it strikes an acceptable balance between First Amendment interests and the laws that regulate false and deceptive advertising.

It is important to note, however, that the use of a disclaimer will be permitted only if the disclaimer effectively converts potentially deceptive speech into nondeceptive speech. For example, in Tambrands, Inc. v. Warner-Lambert Co. ${ }^{176}$ a manufacturer sought a permanent injunction under the Lanham Act to prevent its competitor from making allegedly false claims with respect to its own brand of home pregnancy test kits. In its discussion of the standards governing the issuance of injunctions in false advertising cases, the court stated that

[t]he First Amendment permits courts to enjoin false commercial speech only to the extent necessary to prevent consumer confusion. Disclaimers are preferred over blanket proscriptions of speech. However, a disclaimer, modification or qualifier is appropriate only if it effectively turns an otherwise false advertising claim into a true one, in such a manner that the consumers are not misled. ${ }^{17}$

Applying this standard to the facts at hand, the Tambrands court found that the defendant's claims were "facially false."178 Because some of the claims could not be made true by means of disclaimer or modification, ${ }^{179}$ the court issued the permanent injunction sought. ${ }^{180}$

Courts also are authorized to order corrective advertising. ${ }^{181}$ This is an

175. Id. at 1053. The same court subsequently held, however, without expressly adverting to First Amendment concerns, that if a defendant intends to rely on a disclaimer to make an ambiguous or deceptive ad true, that defendant bears the burden of proving the disclaimer is effective at communicating the truth. Home Box Office, Inc. v. Showtime/The Movie Channel, Inc., 832 F.2d 1311, 1315-16 (2d Cir. 1987).

176. 673 F. Supp. 1190 (S.D.N.Y. 1987).

177. Id. at 1195 (citations omitted). For this reason, courts have held that a defendart cannot rely on a disclaimer which is so inconspicuously located or in such fine print that readers tend to overlook it. See American Home Prods. Corp. v. Johnson \& Johnson, 654 F. Supp. 568, 590 (S.D.N.Y. 1987).

178. Tambrands, 673 F. Supp. at 1199.

179. Id. at 1195. For another case in which a disclaimer was held insufficient to correct a misleading advertising statement, see Home Box Office, Inc. v. Showtime/The Movie Channel, Inc., 832 F.2d 1311 (2d Cir. 1987) (without adverting to First Amendment considerations, court holds that, in the absence of an actual affiliation between Showtime and HBO, disclaimer cannot cure confusion created by slogan "SHOWTIME \& HBO. It's Not Either/Or Anymore.").

180. Tambrands, 673 F. Supp. at 1199.

181. 15 U.S.C. \& 1118 (1994); see, e.g., Taco Cabana Int'l, Inc. v. Two Pesos, Inc., 932 F.2d 1113, 1126 (5th Cir. 1991), aff d, 505 U.S. 763 (1992); ALPO Petfoods, Inc. v. Ralston Purina Co., 720 F. Supp. 194, 
extraordinary remedy, however, and generally is neither favored nor lightly granted by the courts. ${ }^{182}$ Moreover, orders requiring a defendant to publish corrective advertisements may run afoul of the First Amendment. ${ }^{183}$ Nevertheless, corrective advertising can produce less drastic consequences than injunctions against all further sales. In addition, ordering corrective advertising can serve the public interest, and may be appropriate under certain circumstances. ${ }^{184}$

First Amendment concerns also prompted Congress to include an "innocent infringement" defense in the TLRA which makes it harder to sue the print and electronic media. ${ }^{185}$ Under the new provision, malice must be shown in order to hold a member of the media liable for damages in the event of a Lanham Act violation. ${ }^{186}$

\section{$\mathrm{V}$ \\ CONCLUSION}

The application of section 43(a) of the Lanham Act to false advertising claims has created an enormous body of case law that barely existed twenty-five years ago. The adoption of the Trademark Law Revision Act of 1988 should encourage additional claims over the next several decades and, as creative litigants test the outer limits of the statute, further changes in the rules that govern modern advertising.

As competitors continue to expand the limits of section 43(a) by using the statute to monitor how rivals market their products through advertising, increasingly interesting legal issues will arise, especially at the intersection of the Lanham Act and other bodies of law. One thing is clear: The expansion of false advertising law will keep going, and going, and going ....

216 (D.D.C. 1989), affd in pertinent part, 913 F.2d 958 (D.C. Cir. 1990).

182. See, e.g., Burndy Corp. v. Teledyne Indus., 584 F. Supp. 656, 670 (D. Conn.) (no corrective advertising required where misrepresentations have ceased and there is no showing of lingering confusion), aff'd, 748 F.2d 767, 773-74 (2d Cir. 1984). Given the difficulty of procuring this relief, a plaintiff should consider whether to undertake any corrective advertising on its own and thereafter include the cost of the corrective advertising as an element of damages. See ALPO Petfoods, Inc. v. Ralston Purina Co., 913 F.2d 958, 969 (D.C. Cir. 1990).

183. Truthful commercial speech is speech protected by the First Amendment. In re R.M.J., 455 U.S. 191, 203 (1982). Thus, to withstand constitutional attack, any order requiring corrective advertising must (1) be based on a "substantial" government interest; (2) "directly advance[ ] the governmental interest asserted," and (3) not be "more extensive than is necessary to serve that interest." See Central Hudson Gas \& Elec. Corp. v. Public Serv. Comm'n, 447 U.S. 557, 566 (1980). For this reason, the court should not require that defendant publish corrective advertising unless plaintiff can show inter alia (1) actual confusion (if plaintiff shows only a likelihood of confusion, a corrective advertising order may be more extensive than necessary) and (2) that the misrepresentation has had a continuing deceptive effect even after the offending advertisements ceased. See Wamer-Lambert Co. v. FTC, 562 F.2d 749, 762 (D.C. Cir. 1977), cert. denied, 435 U.S. 950 (1978).

184. See Abbott Lab. v. Mead Johnson \& Co., 971 F.2d 6 (7th Cir. 1992).

185. 15 U.S.C. $\S 1114$ (1994).

186. Id. 
